\title{
Postplanting Nutritional Augmentation of Jeffrey Pine Seedlings on an Infertile Sierran Site
}

\author{
Roger F. Walker \\ Department of Natural Resources and Environmental Science, University of Nevada, 1000 Valley Road, Reno, NV 89512, USA \\ Correspondence should be addressed to Roger F. Walker, walker@cabnr.unr.edu
}

Received 20 December 2010; Revised 27 February 2011; Accepted 1 March 2011

Academic Editor: Han Chen

Copyright () 2011 Roger F. Walker. This is an open access article distributed under the Creative Commons Attribution License, which permits unrestricted use, distribution, and reproduction in any medium, provided the original work is properly cited.

Broadcast fertilization with an array of amendments was investigated for its capacity to stimulate growth and enhance nutrition of a three-year-old Jeffrey pine (Pinus jeffreyi Grev. \& Balf.) plantation growing on an acidic Sierra Nevada surface mine. Four formulations that differed in $\mathrm{N}$ source, duration of release, and the suite of nutrients provided were evaluated, with each applied using four rates. Free Flow 29-3-4, a conventional amendment featuring urea as its near exclusive N source, and High N $22-$ $4-6$, a controlled release formulation containing ammoniacal, nitrate, and urea $\mathrm{N}$, were the most stimulatory while an organic formulation relying exclusively on a municipal biosolid N source, Milorganite 6-2-0, was the least so. The lowest application rates employed were inadequate while the most advantageous was not the highest rate for any formulation. Foliar analysis revealed that improved $\mathrm{N}$ nutrition was probably critical in the favorable growth responses to fertilization, that of $\mathrm{P}$ was a likely contributor, and amelioration of potential Mn toxicity may have assumed an accessory role.

\section{Introduction}

Reforestation of infertile sites presents a conundrum for natural resource managers. If the stunting of planted seedlings that frequently results from shortages of critical nutrients is to be averted, it is necessary to devise a nutritional augmentation approach that can rectify the soil deficiencies. Perhaps the most convenient time to implement such an approach is as the seedlings are being planted, but fertilization at planting with conventional amendments has been viewed with skepticism due to a tendency to induce mortality [1-6]. Use of controlled release formulations at planting appears to be somewhat more promising [7-17], with the metering of nutrient release over a prolonged period the likely explanation for their relatively benign impact on survival. Nevertheless, it is not altogether clear that increasing the availability of critical nutrients at a stage when the seedlings are undergoing transplant shock that is immediately followed by further acclimation to an environment generally less hospitable than that in the nursery will yield the maximum growth benefit. Conceivably, delaying fertilization until seedlings are well established on the outplanting site may ultimately prove to be more stimulatory, if less convenient, but questions remain about how long to delay, the application approach, the type and formulation of amendment, and the amount to apply. As for the timing, a delay of sufficient duration to be reasonably assured that fertilization will not impinge on survival would appear prudent, but not so long that malnourishment produces irreversible stunting, and, as for the application approach, it is reasonable to assume that some form of topdressing should be employed, but questions arise concerning the necessity of subsequent tillage of the amendment beneath the soil surface. Regarding the amendment type, choices now extend beyond conventional and controlled release fertilizers to include organic forms, and, for each, the appropriate formulation will likely depend on seedling species as well as soil characteristics. The most advantageous application rate will reflect amendment type and formulation as well as seedling and soil characteristics and may also depend in part on such climatic factors as precipitation regime and ambient temperatures during the growing season.

Harsh sites such as surface mines, which are often infertile $[18,19]$, may pose additional challenges for reforestation programs regardless of whether the objective is to establish a vegetative cover for purposes of site stabilization or a tree 
stand for future harvest of wood fiber. In some cases, they feature substrates lacking in organic matter [20,21], which not only contributes to infertility but also diminishes water retention and the tilth that more productive soils exhibit $[18,19,22,23]$. In others, their soils contain elevated levels of potentially phytotoxic metals [24-27]. Fertilization at planting has sometimes been found to reduce concentrations of several metallic elements as well as increase the uptake of critical nutrients on surface mined sites [16, 17]. If seedling fertilization that is delayed until establishment is assured is to be considered as a means to rectify nutrient deficiencies on harsh sites like surface mines, the capacity to also ameliorate phytotoxicities would frequently constitute a highly desirable ancillary benefit.

Reported here are the results from an investigation of the growth and nutritional responses of Jeffrey pine seedlings on an eastern Sierra Nevada surface mine site to fertilization at the onset of the fourth growing season after outplanting with an assortment of amendments, including conventional, controlled release, and organic formulations, each administered using multiple rates reflecting the chemical composition of the fertilizer. Foliar analysis was employed to provide a physiological interpretation of the responses to treatment regarding alleviation of nutritional deficiencies and potential phytotoxicities.

\section{Methods}

2.1. Study Site. An inactive, open-pit sulfur mine at an elevation of $2200 \mathrm{~m}$ in the eastern Sierra Nevada provided the study site $\left(38^{\circ} 42.50^{\prime} \mathrm{N}, 119^{\circ} 39.25^{\prime} \mathrm{W}\right)$. Excavation ceased in 1962 , but while active, overburden placement outside the pit produced a mine complex of approximately 100 ha. Spoil materials are derived from hydrothermally altered volcanic rock, mostly andesites, and the mine soil is predominantly porous silica with small amounts of montmorillonite clays [25]. The average annual precipitation in the immediate vicinity of the mine is $50 \mathrm{~cm}$ and consists primarily of snowfall. Undisturbed forest stands adjacent to the mine complex indicate that Jeffrey pine was predominant at the study site prior to excavation with California white fir (Abies concolor var. lowiana [Gord.] Lemm.) and Sierra lodgepole pine (Pinus contorta var. murrayana [Grev. \& Balf.] Engelm.) of lesser prevalence. At present, the vegetative cover is sparse and consists primarily of Jeffrey pine established through natural recolonization near the mine periphery and scattered plantings that created small plantations of varying age.

A Jeffrey pine plantation established three years prior to this investigation on a level spoil bench of approximately 0.6 ha was chosen for the study. The planting stock consisted of 2-0 bare-root seedlings (Alpine County, Calif, seed source) grown using conventional methods by the USDA Forest Service Placerville Nursery (Camino, Calif). Plantation spacing was $1.0 \mathrm{~m}$ within rows and $2.0 \mathrm{~m}$ between rows.

To characterize the mine soil prior to treatment, five soil subsamples were collected at a depth of $0-30 \mathrm{~cm}$ from the vicinity of each corner of the bench and from that of its center and combined into one composite sample per location for a total of five composite samples. The composite samples were air-dried for 30 days, sieved to pass a no. 10 ( $2.0 \mathrm{~mm}$ opening) screen, and analyzed as follows: texture by the hydrometer method; organic matter by loss on ignition; $\mathrm{pH}$ by glass electrode on a 1:1 mixture (by weight) of soil and distilled water; total $\mathrm{N}$ by macro-Kjeldahl digestion; $\mathrm{P}$ (Bray 1) colorimetrically after extraction with $\mathrm{NH}_{4} \mathrm{~F}$ and $\mathrm{HCl} ; \mathrm{K}, \mathrm{Ca}, \mathrm{Mg}$, and S by inductively coupled plasma (ICP) spectroscopy after extraction with $\mathrm{NH}_{4} \mathrm{C}_{2} \mathrm{H}_{3} \mathrm{O}_{2} ; \mathrm{Fe}, \mathrm{Mn}$, $\mathrm{Zn}, \mathrm{Cu}$, and $\mathrm{B}$ by ICP spectroscopy after extraction with $\mathrm{HCl}$; and $\mathrm{Al}$ by ICP spectroscopy after extraction with $\mathrm{KCl}$ $[28,29]$. These analyses revealed the following physical and chemical properties: $68 \%$ sand, $20 \%$ silt, and $12 \%$ clay (sandy loam textural class); organic matter: 0.2\%; pH: 4.5; total N: $631 \mu \mathrm{g} \mathrm{g}^{-1}$; P (Bray 1): $24 \mu \mathrm{g} \mathrm{g}^{-1} ; \mathrm{K}: 266 \mu \mathrm{g} \mathrm{g}^{-1}$; Ca: $3342 \mu \mathrm{g} \mathrm{g}^{-1}$; Mg: $388 \mu \mathrm{gg}^{-1}$; S: $301 \mu \mathrm{gg}^{-1}$; Fe: $309 \mu \mathrm{gg}^{-1}$; Mn: $113 \mu \mathrm{gg}^{-1}$; Zn: $3.9 \mu \mathrm{g} \mathrm{g}^{-1}$; Cu: $24.4 \mu \mathrm{gg}^{-1}$; B: $1.1 \mu \mathrm{g} \mathrm{g}^{-1}$; $\mathrm{Al}: 259 \mu \mathrm{g} \mathrm{g}^{-1}$. The coarse texture and near absence of organic matter in this mine soil, coupled with the sparse growing season precipitation, suggest that moisture stress imposes a limitation on growth sufficient to compromise the success of nutritional augmentation. Furthermore, compared to routine eastern Sierran forest soils occupied by Jeffrey pine $[13,30,31]$, it is more acidic and lower in $\mathrm{N}$ and $\mathrm{P}$ but higher in all of the other elements included in the analyses, with the disparities of sufficient magnitude for both nutritional deficiencies and phytotoxicities to be of concern in reforestation efforts.

2.2. Study Installation. Immediately following soil sample collection, 85 plots were delineated for the study, with each consisting of 10 consecutive seedlings within a single plantation row. One of 17 treatments was then assigned to each of five randomly selected plots, creating a completely randomized experimental design. The treatments consisted of administering one of four amendment formulations using one of four application rates per formulation plus a nonfertilized control. The formulations were as follows: Viking Brand 21-7-14 Royale fertilizer (Hydro Agri North America, Inc., Tampa, Fla), Free Flow 29-3-4 Poly-S fertilizer (Free Flow Fertilizer, Maumee, Ohio), High N 22-4$6+$ Minors controlled release fertilizer (Scotts Company, Marysville, Ohio), and Milorganite Greens Grade 6-2-0 + Iron organic fertilizer (Milwaukee Metropolitan Sewerage District, Milwaukee, Wis). Amounts of individual nutrients supplied by each formulation appear in Table 1, with $\mathrm{N}$ indicated by source. Application rates for the first three formulations were $25 \mathrm{~g}, 50 \mathrm{~g}, 75 \mathrm{~g}$, and $100 \mathrm{~g}$ per seedling while those for the latter formulation were $100 \mathrm{~g}, 200 \mathrm{~g}, 300 \mathrm{~g}$, and $400 \mathrm{~g}$. The fertilizers were applied in April by surface broadcasting, without tillage into the soil, in a $0.5 \mathrm{~m}$ diameter circle centered at the seedling base.

2.3. Growth Measurements. Initial measurements of seedling height and stem diameter at the ground line were made at fertilization, with subsequent measurements completed at the conclusion of the second posttreatment growing season and then again at the conclusion of the fourth growing season thereafter. These dimension measurements were used to calculate an estimate of shoot volume by the formula of 
TABle 1: Percent by weight of macronutrients and micronutrients provided by Viking Brand 21-7-14, Free Flow 29-3-4, High N 22-4$6+$ Minors, and Milorganite 6-2-0 fertilizer formulations.

\begin{tabular}{lcccc}
\hline \multirow{2}{*}{ Nutrient } & \multicolumn{4}{c}{ Fertilizer } \\
& $\begin{array}{c}\text { Viking } \\
\text { Brand } \\
21-7-14\end{array}$ & $\begin{array}{c}\text { Free Flow } \\
29-3-4\end{array}$ & $\begin{array}{c}\text { High N } \\
22-4-6\end{array}$ & $\begin{array}{c}\text { Milorganite } \\
6-2-0\end{array}$ \\
\hline $\mathrm{N}$ & 11.0 & 1.2 & 5.9 & 0 \\
(ammoniacal) & & & 5.3 & 0 \\
$\mathrm{~N}$ (nitrate) & 10.0 & 0 & 10.8 & 0 \\
$\mathrm{~N}$ (urea) & 0 & 27.8 & 22.0 & $6.0^{\mathrm{a}}$ \\
$\mathrm{N}$ (total) & 21.0 & 29.0 & 4 & 2.0 \\
$\mathrm{P}\left(\mathrm{P}_{2} \mathrm{O}_{5}\right)$ & 7 & 3 & 6 & 0 \\
$\mathrm{~K}\left(\mathrm{~K}_{2} \mathrm{O}\right)$ & 14 & 4 & 1 & 0 \\
$\mathrm{Ca}$ & 0 & 0 & 1 & 0 \\
$\mathrm{Mg}$ & 0 & 0 & 3.0 & 0 \\
$\mathrm{~S}$ & 5.0 & 3.9 & 1 & 4.0 \\
$\mathrm{Fe}$ & 0 & 2 & 0.1 & 0 \\
$\mathrm{Mn}$ & 0 & 0 & 0.05 & 0 \\
$\mathrm{Zn}$ & 0 & 0 & 0.05 & 0 \\
$\mathrm{Cu}$ & 0 & 0 & 0.02 & 0 \\
$\mathrm{~B}$ & 0 & 0 & 0.001 & 0 \\
$\mathrm{Mo}$ & 0 & 0 & & \\
\hline $\mathrm{Deniv}$ & & & & \\
\hline
\end{tabular}

${ }^{a}$ Derived from municipal biosolids.

Ruehle et al. [32]. For dimension measurements and volume estimates, relative growth was calculated after the second posttreatment season based on seedling size at fertilization (seasons 0-2), after the fourth posttreatment season based on seedling size at the conclusion of the second season (seasons 2-4), and after the fourth season based on seedling size at fertilization (seasons 0-4). By accommodating differences in initial size, these relative growth calculations provide a more accurate assessment of early, late, and overall growth responses to treatment, respectively. Concurrent with field measurements of height and diameter, an assessment of seedling survival within each of the 85 plots was conducted to gauge treatment impacts on mortality.

2.4. Foliar Analysis. Current-year needle subsamples were collected from each seedling in every plot during the fourth week of July in the second and fourth posttreatment growing seasons and combined into composite samples segregated by plot and season. The needles were approximately $80 \%$ elongated when collected. All samples were dried at $75^{\circ} \mathrm{C}$ for 24 hours, ground to pass a 20 -mesh $(850 \mu \mathrm{m}$ opening) screen, and then analyzed for total $\mathrm{N}$ using a Leco Model FP428 N Analyzer (LECO Corp., St. Joseph, Mich) and for P, $\mathrm{K}, \mathrm{Ca}, \mathrm{Mg}, \mathrm{S}, \mathrm{Fe}, \mathrm{Mn}, \mathrm{Zn}, \mathrm{Cu}, \mathrm{B}$, and Al by ICP spectroscopy after wet ashing with $\mathrm{HNO}_{3}$ and $\mathrm{HClO}_{4}$ [33].

2.5. Statistical Analysis. Relative growth data concerned with seasons $0-2$ and 2-4 plus all nutritional data derived from this completely randomized experiment were subjected to repeated measures, mixed model analysis of variance
(ANOVA) with five replications of each of 17 treatments. This analysis incorporated the compound symmetry covariance structure, and effects of treatment and season, along with their interaction, were considered significant only when $P \leq .05$ according to the $F$ test. Growth data concerned with seasons 0-4 were subjected to one-way ANOVA, again with five replications of each of 17 treatments, and here also treatment effects were considered significant when $P \leq .05$. Differences among means were evaluated using the least significant difference (LSD) test with $\alpha=.05$. All statistical analyses were accomplished using the Statistical Analysis System (SAS Institute, Inc., Cary, NC). In the presentation of results that follows, $P$ values are included in the text when the treatment, season, or interaction effect proved significant as determined through ANOVA, while the mean separation analysis embodied in the LSD test was relied upon to provide insight into the influences of individual amendment formulations and application rates.

\section{Results}

3.1. Growth Responses. At fertilization, differences among treatments in seedling height and diameter were nonsignificant according to the LSD test (Table 2). Overall, the average height was $23.7 \mathrm{~cm}$ initially, and the average diameter was $10.8 \mathrm{~mm}$. Above-ground volume was greater initially in seedlings fertilized with the Viking formulation applied at the $25 \mathrm{~g}$ rate than in those receiving $100 \mathrm{~g}$ of the Free Flow amendment, with all other treatments assuming intermediate values that did not differ statistically according to the LSD test from the former or the latter. The average seedling volume at fertilization was $36.5 \mathrm{~cm}^{3}$ overall. For the duration of the study, mortality was entirely absent in every seedling plot regardless of treatment.

Repeated measures ANOVA revealed a significant fertilization treatment influence $(P=.0495)$ on the relative growth in seedling height (Table 2). For seasons 0-2, differences among treatments identified as significant by the LSD test consisted of those between the $50 \mathrm{~g}$ application of the High $\mathrm{N}$ formulation, the highest overall value numerically, and $25 \mathrm{~g}$ of Free Flow, $300 \mathrm{~g}$ of Milorganite, and the nonfertilized control, with the latter producing the lowest overall numerical value. During seasons $2-4$, the $50 \mathrm{~g}$ rate of the Free Flow amendment, which produced the highest numerical value, plus the $75 \mathrm{~g}$ rate of the Viking and High $\mathrm{N}$ formulations along with the $100 \mathrm{~g}$ rate of the Viking, Free Flow, and High $\mathrm{N}$ amendments all proved to be more stimulatory than the nonfertilized control according to this test, with the latter again producing the lowest numerical value overall. Additionally, the $50 \mathrm{~g}$ application of Free Flow produced significantly greater relative height growth in seasons 2-4 than the lowest rates of any of the four formulations as well as the $200 \mathrm{~g}$ application of Milorganite. One-way ANOVA also revealed a significant treatment effect on relative height growth for seasons $0-4(P=.0498)$, with the $50 \mathrm{~g}$ High $\mathrm{N}$ application, which produced the highest numerical value, along with $50 \mathrm{~g}$ of Free Flow inducing significantly greater growth than the control according to the LSD test. 
TABLE 2: Initial dimensions and effects of conventional, controlled release, and organic fertilizer formulations on relative growth of Jeffrey pine seedlings. ${ }^{\mathrm{a}}$

\begin{tabular}{|c|c|c|c|c|c|c|c|c|c|c|c|c|}
\hline \multirow{2}{*}{$\begin{array}{l}\text { Formulation and } \\
\text { application rate }\end{array}$} & \multicolumn{4}{|c|}{ Height } & \multicolumn{4}{|c|}{ Diameter } & \multicolumn{4}{|c|}{ Volume } \\
\hline & $\begin{array}{c}\text { Initial } \\
(\mathrm{cm})\end{array}$ & $\begin{array}{l}\text { Seasons } \\
0-2\end{array}$ & $\begin{array}{c}\text { Seasons } \\
2-4\end{array}$ & $\begin{array}{c}\text { Seasons } \\
0-4\end{array}$ & $\begin{array}{l}\text { Initial } \\
(\mathrm{mm})\end{array}$ & $\begin{array}{l}\text { Seasons } \\
0-2\end{array}$ & $\begin{array}{c}\text { Seasons } \\
2-4\end{array}$ & $\begin{array}{c}\text { Seasons } \\
0-4\end{array}$ & $\begin{array}{l}\text { Initial } \\
\left(\mathrm{cm}^{3}\right)\end{array}$ & $\begin{array}{c}\text { Seasons } \\
0-2\end{array}$ & $\begin{array}{c}\text { Seasons } \\
2-4\end{array}$ & $\begin{array}{c}\text { Seasons } \\
0-4\end{array}$ \\
\hline \multicolumn{13}{|l|}{ Viking 21-7-14 } \\
\hline $25 \mathrm{~g}$ & $25.8 \mathrm{a}$ & $0.51 \mathrm{ab}$ & $0.38 \mathrm{bc}$ & $1.17 \mathrm{ab}$ & $11.3 \mathrm{a}$ & $0.71 \mathrm{ab}$ & $0.35 b c$ & $1.38 \mathrm{ab}$ & $54.1 \mathrm{a}$ & $4.05 \mathrm{ab}$ & $1.68 \mathrm{bc}$ & $15.40 \mathrm{ab}$ \\
\hline $50 \mathrm{~g}$ & $23.6 \mathrm{a}$ & $0.44 \mathrm{ab}$ & $0.46 \mathrm{abc}$ & $1.14 \mathrm{ab}$ & $11.0 \mathrm{a}$ & $0.67 \mathrm{ab}$ & $0.38 \mathrm{bc}$ & $1.36 \mathrm{ab}$ & $37.1 \mathrm{ab}$ & $3.36 \mathrm{abc}$ & $1.98 \mathrm{abc}$ & $13.13 \mathrm{ab}$ \\
\hline $75 \mathrm{~g}$ & $24.7 \mathrm{a}$ & $0.55 \mathrm{ab}$ & $0.52 \mathrm{ab}$ & $1.37 \mathrm{ab}$ & $10.9 \mathrm{a}$ & $0.82 \mathrm{a}$ & $0.43 \mathrm{abc}$ & $1.64 \mathrm{a}$ & $36.4 \mathrm{ab}$ & $4.71 \mathrm{a}$ & $2.26 a b c$ & $19.36 \mathrm{ab}$ \\
\hline $100 \mathrm{~g}$ & $22.6 a$ & $0.48 \mathrm{ab}$ & $0.53 \mathrm{ab}$ & $1.32 \mathrm{ab}$ & $10.2 \mathrm{a}$ & $0.66 \mathrm{ab}$ & $0.40 \mathrm{abc}$ & $1.36 \mathrm{ab}$ & $27.8 \mathrm{ab}$ & $3.43 \mathrm{abc}$ & $2.14 \mathrm{abc}$ & $14.88 \mathrm{ab}$ \\
\hline \multicolumn{13}{|l|}{ Free Flow 29-3-4 } \\
\hline $25 \mathrm{~g}$ & $24.0 \mathrm{a}$ & $0.36 b$ & $0.38 \mathrm{bc}$ & $0.91 \mathrm{ab}$ & $10.7 \mathrm{a}$ & $0.60 \mathrm{ab}$ & $0.36 \mathrm{bc}$ & $1.21 \mathrm{ab}$ & $34.3 \mathrm{ab}$ & $2.94 \mathrm{bc}$ & $1.68 \mathrm{bc}$ & $11.19 \mathrm{ab}$ \\
\hline $50 \mathrm{~g}$ & $25.4 \mathrm{a}$ & $0.53 \mathrm{ab}$ & $0.64 \mathrm{a}$ & $1.53 \mathrm{a}$ & $11.2 \mathrm{a}$ & $0.75 a$ & $0.55 \mathrm{a}$ & $1.75 \mathrm{a}$ & $35.4 \mathrm{ab}$ & $4.25 \mathrm{ab}$ & $3.18 \mathrm{a}$ & $22.26 \mathrm{a}$ \\
\hline $75 \mathrm{~g}$ & $23.8 \mathrm{a}$ & $0.52 \mathrm{ab}$ & $0.48 \mathrm{abc}$ & $1.34 \mathrm{ab}$ & $11.3 \mathrm{a}$ & $0.74 \mathrm{a}$ & $0.42 \mathrm{abc}$ & $1.53 \mathrm{ab}$ & $39.3 \mathrm{ab}$ & $4.51 \mathrm{a}$ & $2.16 \mathrm{abc}$ & $20.46 \mathrm{a}$ \\
\hline $100 \mathrm{~g}$ & $21.2 \mathrm{a}$ & $0.43 \mathrm{ab}$ & $0.55 \mathrm{ab}$ & $1.24 \mathrm{ab}$ & $9.2 \mathrm{a}$ & $0.70 \mathrm{ab}$ & $0.44 \mathrm{abc}$ & $1.50 \mathrm{ab}$ & $20.9 b$ & $3.71 \mathrm{abc}$ & $2.41 \mathrm{abc}$ & $17.50 \mathrm{ab}$ \\
\hline \multicolumn{13}{|l|}{ High N 22-4-6 } \\
\hline $25 \mathrm{~g}$ & $22.1 \mathrm{a}$ & $0.48 \mathrm{ab}$ & $0.41 b c$ & $1.16 \mathrm{ab}$ & $10.2 \mathrm{a}$ & $0.64 \mathrm{ab}$ & $0.43 \mathrm{abc}$ & $1.40 \mathrm{ab}$ & $28.6 \mathrm{ab}$ & $3.70 \mathrm{abc}$ & $2.12 \mathrm{abc}$ & $17.01 \mathrm{ab}$ \\
\hline $50 \mathrm{~g}$ & $24.4 \mathrm{a}$ & $0.68 \mathrm{a}$ & $0.49 \mathrm{abc}$ & $1.62 \mathrm{a}$ & $12.3 \mathrm{a}$ & $0.69 \mathrm{ab}$ & $0.44 \mathrm{abc}$ & $1.47 \mathrm{ab}$ & $45.8 \mathrm{ab}$ & $4.51 \mathrm{a}$ & $2.28 \mathrm{abc}$ & $19.67 \mathrm{ab}$ \\
\hline $75 \mathrm{~g}$ & $25.7 \mathrm{a}$ & $0.52 \mathrm{ab}$ & $0.54 \mathrm{ab}$ & $1.38 \mathrm{ab}$ & $11.6 \mathrm{a}$ & $0.67 \mathrm{ab}$ & $0.54 \mathrm{a}$ & $1.62 \mathrm{a}$ & $45.0 \mathrm{ab}$ & $3.63 \mathrm{abc}$ & $2.93 \mathrm{ab}$ & $20.54 \mathrm{a}$ \\
\hline $100 \mathrm{~g}$ & $24.6 \mathrm{a}$ & $0.44 \mathrm{ab}$ & $0.56 \mathrm{ab}$ & $1.33 \mathrm{ab}$ & $11.4 \mathrm{a}$ & $0.62 \mathrm{ab}$ & $0.52 \mathrm{ab}$ & $1.47 \mathrm{ab}$ & $43.1 \mathrm{ab}$ & $3.26 \mathrm{abc}$ & $2.77 \mathrm{ab}$ & $16.79 \mathrm{ab}$ \\
\hline \multicolumn{13}{|l|}{ Milorganite 6-2-0 } \\
\hline $100 \mathrm{~g}$ & $22.2 \mathrm{a}$ & $0.50 \mathrm{ab}$ & $0.41 \mathrm{bc}$ & $1.17 \mathrm{ab}$ & $10.1 \mathrm{a}$ & $0.59 \mathrm{ab}$ & $0.44 \mathrm{abc}$ & $1.34 \mathrm{ab}$ & $28.7 \mathrm{ab}$ & $3.33 \mathrm{abc}$ & $2.06 \mathrm{bc}$ & $14.95 \mathrm{ab}$ \\
\hline $200 \mathrm{~g}$ & $25.0 \mathrm{a}$ & $0.50 \mathrm{ab}$ & $0.32 \mathrm{bc}$ & $1.06 \mathrm{ab}$ & $11.7 \mathrm{a}$ & $0.50 \mathrm{ab}$ & $0.32 \mathrm{c}$ & $1.01 \mathrm{ab}$ & $48.9 \mathrm{ab}$ & $2.82 \mathrm{bc}$ & $1.49 \mathrm{bc}$ & $10.63 \mathrm{ab}$ \\
\hline $300 \mathrm{~g}$ & $23.1 \mathrm{a}$ & $0.37 \mathrm{~b}$ & $0.45 \mathrm{abc}$ & $1.05 \mathrm{ab}$ & $10.2 \mathrm{a}$ & $0.54 \mathrm{ab}$ & $0.38 b c$ & $1.17 \mathrm{ab}$ & $30.4 \mathrm{ab}$ & $2.81 b c$ & $1.94 \mathrm{bc}$ & $12.61 \mathrm{ab}$ \\
\hline $400 \mathrm{~g}$ & $22.7 \mathrm{a}$ & $0.48 \mathrm{ab}$ & $0.42 \mathrm{abc}$ & $1.26 \mathrm{ab}$ & $10.4 \mathrm{a}$ & $0.57 \mathrm{ab}$ & $0.44 \mathrm{abc}$ & $1.33 \mathrm{ab}$ & $30.6 \mathrm{ab}$ & $3.52 \mathrm{abc}$ & $2.25 \mathrm{abc}$ & $19.72 \mathrm{ab}$ \\
\hline Nonfertilized & $22.7 \mathrm{a}$ & $0.32 b$ & $0.22 c$ & $0.69 \mathrm{~b}$ & $10.5 a$ & $0.39 \mathrm{~b}$ & $0.27 \mathrm{c}$ & $0.81 \mathrm{~b}$ & $34.5 \mathrm{ab}$ & $2.02 \mathrm{c}$ & $1.13 c$ & $7.80 \mathrm{~b}$ \\
\hline
\end{tabular}

For relative growth in stem diameter, repeated measures ANOVA revealed the season of measurement $(P<.0001)$ along with the fertilization treatment effect $(P=.0472)$ to be significant (Table 2). The former reflects that relative growth in this dimension declined from seasons $0-2$ to seasons 24 regardless of treatment. As for the latter, the LSD test revealed that, for seasons $0-2,75 \mathrm{~g}$ of the Viking formulation, which yielded the highest value numerically, along with the $50 \mathrm{~g}$ and $75 \mathrm{~g}$ applications of Free Flow differed significantly from the nonfertilized treatment, which yielded the lowest value overall. For seasons 2-4, however, $50 \mathrm{~g}$ of Free Flow as well as $75 \mathrm{~g}$ and $100 \mathrm{~g}$ of High $\mathrm{N}$ produced growth rates exceeding those of the $200 \mathrm{~g}$ application of Milorganite and the nonfertilized control, with the latter again yielding the lowest numerical value. Furthermore, the $50 \mathrm{~g}$ application of the Free Flow amendment and $75 \mathrm{~g}$ of High $\mathrm{N}$ produced values exceeding those resulting from the $25 \mathrm{~g}$ and $50 \mathrm{~g}$ applications of the Viking formulation, the $25 \mathrm{~g}$ application of Free Flow, and the $300 \mathrm{~g}$ application of Milorganite. As for seasons $0-4$, a significant treatment effect on relative diameter growth identified by one-way ANOVA $(P=.0488)$ was accompanied by disparities according to the LSD test between the $50 \mathrm{~g}$ Free Flow treatment, which induced the greatest growth numerically, along with the $75 \mathrm{~g}$ applications of the Viking and High $\mathrm{N}$ amendments, and the control treatment.

Regarding relative growth in seedling volume, repeated measures ANOVA again revealed that the season of measurement $(P<.0001)$ along with the fertilization treatment effect $(P=.0484)$ was significant (Table 2), with the former reflecting that relative volume growth also declined from seasons $0-2$ to seasons $2-4$ in all treatments. As for fertilization influences, the LSD test indicated that the $25 \mathrm{~g}$ and $75 \mathrm{~g}$ applications of the Viking amendment, the $50 \mathrm{~g}$ and $75 \mathrm{~g}$ applications of the Free Flow amendment, and the $50 \mathrm{~g}$ application of High $\mathrm{N}$ all produced values in seasons 0-2 significantly exceeding that of the nonfertilized control, which yielded the lowest value overall. For the same time period, $75 \mathrm{~g}$ of the Viking and Free Flow formulations and $50 \mathrm{~g}$ of High $\mathrm{N}$ also produced values greater than those generated by $25 \mathrm{~g}$ of Free Flow or either $200 \mathrm{~g}$ or $300 \mathrm{~g}$ of Milorganite. For seasons 2-4, $50 \mathrm{~g}$ of Free Flow, which yielded the highest value numerically, along with the $75 \mathrm{~g}$ and $100 \mathrm{~g}$ applications of High $\mathrm{N}$, produced values significantly exceeding those in the nonfertilized control, which again yielded the lowest value overall, and that produced by the former also exceeded those associated with $25 \mathrm{~g}$ of the Viking and Free Flow formulations as well as the $100 \mathrm{~g}, 200 \mathrm{~g}$, and 
$300 \mathrm{~g}$ applications of Milorganite. A significant treatment effect on relative volume growth for seasons $0-4$ was indicated by one-way ANOVA as well $(P=.0492)$, and the LSD test identified the $50 \mathrm{~g}$ Free Flow treatment, which provided the highest numerical value, along with the $75 \mathrm{~g}$ applications of Free Flow and High N as disparate from the control, which exhibited the least growth.

3.2. Macronutrient Concentrations. Concentrations of all of the macronutrients included in the foliar analysis were significantly affected by fertilization treatment, specifically $\mathrm{N}(P=.0113), \mathrm{P}(P=.0009), \mathrm{K}(P<.0001), \mathrm{Ca}(P<$ $.0001), \operatorname{Mg}(P=.0329)$, and $\mathrm{S}(P<.0001)$ according to repeated measures ANOVA (Table 3 ). For N only, the season of sampling was also significant $(P<.0001)$ along with the treatment $\times$ season interaction effect $(P=.0475)$. According to the LSD test, the $\mathrm{N}$ concentration in the nonfertilized treatment was exceeded by that in all other treatments during both the second and fourth posttreatment seasons. Additionally, during the second season, it was significantly higher with the $75 \mathrm{~g}$ application of Free Flow than with the $25 \mathrm{~g}$ or $50 \mathrm{~g}$ applications of the Viking formulation, the $25 \mathrm{~g}$ application of High $\mathrm{N}$, or the $100 \mathrm{~g}, 200 \mathrm{~g}$, or $300 \mathrm{~g}$ applications of Milorganite. Furthermore, it was higher with the $100 \mathrm{~g}$ applications of either the Viking or Free Flow formulations than with $25 \mathrm{~g}$ of the former, $25 \mathrm{~g}$ of High $\mathrm{N}$, or $100 \mathrm{~g}$ of Milorganite, and it was higher with $75 \mathrm{~g}$ of the Viking amendment, $50 \mathrm{~g}$ of Free Flow, $100 \mathrm{~g}$ of High N, or $400 \mathrm{~g}$ of Milorganite than with $25 \mathrm{~g}$ of High $\mathrm{N}$ or $100 \mathrm{~g}$ of Milorganite. During the fourth season, foliar $\mathrm{N}$ was greater with the $100 \mathrm{~g}$ application of High $\mathrm{N}$ than with any rate of the Viking or Milorganite amendments or with $25 \mathrm{~g}$ or $50 \mathrm{~g}$ of Free Flow, and it was greater with the $75 \mathrm{~g}$ or $100 \mathrm{~g}$ applications of Free Flow and the $50 \mathrm{~g}$ and $75 \mathrm{~g}$ applications of High $\mathrm{N}$ than with $25 \mathrm{~g}$ or $50 \mathrm{~g}$ of the Viking formulation or the $100 \mathrm{~g}$ or $200 \mathrm{~g}$ applications of Milorganite. Except for the treatments consisting of $50 \mathrm{~g}, 75 \mathrm{~g}$, or $100 \mathrm{~g}$ of the Viking formulation, $\mathrm{N}$ concentrations increased from the second to the fourth seasons, with the disparities largest overall in the High N treatments.

The $\mathrm{P}$ concentration in the nonfertilized treatment was exceeded by those in all other treatments during the second season according to the LSD test and was exceeded by those produced by all rates of the High $\mathrm{N}$ amendment, all except the $25 \mathrm{~g}$ rate of the Viking formulation, the $50 \mathrm{~g}$ and $75 \mathrm{~g}$ rates of Free Flow, and the $200 \mathrm{~g}$ rate of Milorganite during the fourth season (Table 3). Similarly, the K concentration in the nonfertilized control was also exceeded by those in all other treatments during the second season and, for the fourth season, was exceeded by those resulting from every rate of the Viking applications except $25 \mathrm{~g}$ along with the $75 \mathrm{~g}$ rate of Free Flow, the $50 \mathrm{~g}$ and $75 \mathrm{~g}$ rates of High $\mathrm{N}$, and $200 \mathrm{~g}$ of Milorganite. Additionally, the K concentrations associated with the $75 \mathrm{~g}$ application of High $\mathrm{N}$ and the $100 \mathrm{~g}$ application of Milorganite exceeded those produced by $100 \mathrm{~g}$ of the Viking formulation or $75 \mathrm{~g}$ of Free Flow during the second season.

For $\mathrm{Ca}$, the foliar concentration in the nonfertilized treatment exceeded those in all other treatments during both the second and fourth seasons according to the LSD test, and, to a lesser extent, a somewhat similar pattern in the nutritional responses to treatment was evident for $\mathrm{Mg}$ and S (Table 3). Specifically, the Mg concentration in the nonfertilized control during the second season exceeded those associated with every rate of the Viking amendment, every rate of Free Flow except $25 \mathrm{~g}$, every rate of High N except $50 \mathrm{~g}$, and the $100 \mathrm{~g}$ rate of Milorganite. During the fourth season, it exceeded those associated with the $75 \mathrm{~g}$ and $100 \mathrm{~g}$ applications of High N only, however. For S, the concentration in the control treatment exceeded those associated with the $50 \mathrm{~g}$ Viking application, all rates of Free Flow, and the $75 \mathrm{~g}$ and $100 \mathrm{~g}$ applications of High $\mathrm{N}$ during the second season, and, in the fourth season, it exceeded those associated with the $25 \mathrm{~g}, 75 \mathrm{~g}$, and $100 \mathrm{~g}$ applications of the Viking formulation, all rates of Free Flow and High N, and the $100 \mathrm{~g}$ and $400 \mathrm{~g}$ applications of Milorganite. Additional significant disparities identified by the LSD test for $\mathrm{Mg}$ consisted of a higher concentration in the $25 \mathrm{~g}$ Free Flow treatment, the $50 \mathrm{~g}$ High $\mathrm{N}$ treatment, and the $200 \mathrm{~g}, 300 \mathrm{~g}$, and $400 \mathrm{~g}$ Milorganite treatments than in the $100 \mathrm{~g}$ Viking treatment during the second season and a higher concentration in the $25 \mathrm{~g}$ Viking and $400 \mathrm{~g}$ Milorganite treatments than in the $100 \mathrm{~g}$ High $\mathrm{N}$ treatment during the fourth season. Additional differences in foliar $\mathrm{S}$ during the second season consisted of a higher concentration in the $200 \mathrm{~g}$ Milorganite treatment than in the $50 \mathrm{~g}$ Viking treatment, the $50 \mathrm{~g}, 75 \mathrm{~g}$, and $100 \mathrm{~g}$ Free Flow treatments, and the $75 \mathrm{~g}$ and $100 \mathrm{~g}$ High $\mathrm{N}$ treatments plus higher concentrations in the $75 \mathrm{~g}$ and $100 \mathrm{~g}$ Viking treatments, the $50 \mathrm{~g}$ High $\mathrm{N}$ treatment, and the $300 \mathrm{~g}$ and $400 \mathrm{~g}$ Milorganite treatments than that in the $100 \mathrm{~g}$ Free Flow treatment. Additional $S$ disparities during the fourth season were limited to a higher concentration in the $200 \mathrm{~g}$ Milorganite treatment than those found in the $100 \mathrm{~g}$ Free Flow and High N treatments.

3.3. Micronutrient and Al Concentrations. As was the case for all macronutrients, concentrations of all of the micronutrients included in the foliar analysis were significantly affected by fertilization treatment, specifically $\mathrm{Fe}(P=$ $.0385), \mathrm{Mn}(P<.0001), \mathrm{Zn}(P<.0001), \mathrm{Cu}(P=$ $.0352)$, and $\mathrm{B}(P=.0003)$ according to repeated measures ANOVA (Table 3). For $\mathrm{Cu}$ only, the season of sampling was also significant $(P=.0003)$. As indicated by the LSD test, the Fe and $\mathrm{Mn}$ concentrations in the nonfertilized control significantly exceeded those in all other treatments during the second season. During the fourth season, the Fe concentration in the control exceeded those in the $25 \mathrm{~g}$, $75 \mathrm{~g}$, and $100 \mathrm{~g}$ Viking treatments, all except the $25 \mathrm{~g}$ rate among the Free Flow treatments, the $50 \mathrm{~g}$ and $75 \mathrm{~g}$ rates of High N, and all Milorganite treatments except the $400 \mathrm{~g}$ rate. Additional significant differences in Fe during the fourth season consisted of a higher concentration in the $50 \mathrm{~g}$ Viking treatment than in the $50 \mathrm{~g}$ Free Flow treatment, the $75 \mathrm{~g}$ High $\mathrm{N}$ treatment, and the $100 \mathrm{~g}$ Milorganite treatment, higher concentrations in the $25 \mathrm{~g}$ Free Flow and High $\mathrm{N}$ treatments and the $400 \mathrm{~g}$ Milorganite treatment than in the $50 \mathrm{~g}$ Free Flow and $75 \mathrm{~g}$ High $\mathrm{N}$ treatments, and higher concentrations 
TABLE 3: Foliar concentrations of nutrients and $\mathrm{Al}$ in Jeffrey pine seedlings during the second and fourth growing seasons as affected by conventional, controlled release, and organic fertilizer formulations. ${ }^{\mathrm{a}}$

\begin{tabular}{|c|c|c|c|c|c|c|c|c|c|c|c|c|}
\hline \multirow{2}{*}{$\begin{array}{l}\text { Formulation and } \\
\text { application rate }\end{array}$} & \multicolumn{6}{|c|}{ Macronutrient concentration (\%) } & \multicolumn{5}{|c|}{ Micronutrient concentration $\left(\mu \mathrm{g} \mathrm{g}^{-1}\right)$} & \multirow{2}{*}{$\mathrm{Al}\left(\mu \mathrm{gg}^{-1}\right)$} \\
\hline & $\mathrm{N}$ & $\mathrm{P}$ & $\mathrm{K}$ & $\mathrm{Ca}$ & $\mathrm{Mg}$ & $S$ & $\mathrm{Fe}$ & $\mathrm{Mn}$ & $\mathrm{Zn}$ & $\mathrm{Cu}$ & B & \\
\hline \multicolumn{13}{|c|}{ Second posttreatment season: } \\
\hline \multicolumn{13}{|c|}{ Viking 21-7-14 } \\
\hline $25 \mathrm{~g}$ & $1.11 \mathrm{~cd}$ & $0.15 \mathrm{a}$ & $0.96 \mathrm{ab}$ & $0.24 b$ & $0.09 \mathrm{bc}$ & $0.22 \mathrm{abcd}$ & $65 b$ & $684 b$ & $36 b c$ & $5.0 \mathrm{abc}$ & $54 \mathrm{~b}$ & $176 b$ \\
\hline $50 \mathrm{~g}$ & $1.18 \mathrm{bcd}$ & $0.15 a$ & $0.98 \mathrm{ab}$ & $0.21 b$ & $0.09 \mathrm{bc}$ & $0.18 \mathrm{~cd}$ & $58 \mathrm{~b}$ & $458 b$ & $31 c d$ & $5.6 \mathrm{ab}$ & $37 \mathrm{~b}$ & $132 b$ \\
\hline $75 \mathrm{~g}$ & $1.27 \mathrm{abc}$ & $0.15 \mathrm{a}$ & $1.07 \mathrm{ab}$ & $0.18 \mathrm{~b}$ & $0.09 \mathrm{bc}$ & $0.24 \mathrm{abc}$ & $57 \mathrm{~b}$ & $502 b$ & $30 \mathrm{~cd}$ & $5.8 \mathrm{ab}$ & $45 b$ & $143 b$ \\
\hline $100 \mathrm{~g}$ & $1.38 \mathrm{ab}$ & $0.15 \mathrm{a}$ & $0.95 b$ & $0.20 \mathrm{~b}$ & $0.08 \mathrm{c}$ & $0.24 \mathrm{abc}$ & $130 \mathrm{~b}$ & $442 b$ & $31 \mathrm{~cd}$ & $5.8 \mathrm{ab}$ & $37 b$ & $113 \mathrm{~b}$ \\
\hline \multicolumn{13}{|l|}{ Free Flow 29-3-4 } \\
\hline $25 \mathrm{~g}$ & $1.22 \mathrm{abcd}$ & $0.16 \mathrm{a}$ & $0.96 \mathrm{ab}$ & $0.22 b$ & $0.10 \mathrm{ab}$ & $0.20 \mathrm{bcd}$ & $63 b$ & $494 b$ & $29 \mathrm{~cd}$ & $5.2 \mathrm{abc}$ & $39 b$ & $152 b$ \\
\hline $50 \mathrm{~g}$ & $1.28 \mathrm{abc}$ & $0.16 \mathrm{a}$ & $1.04 \mathrm{ab}$ & $0.19 b$ & $0.09 b c$ & $0.19 \mathrm{~cd}$ & $61 b$ & $381 b$ & $29 \mathrm{~cd}$ & $5.2 \mathrm{abc}$ & $35 b$ & $123 b$ \\
\hline $75 \mathrm{~g}$ & $1.40 \mathrm{a}$ & $0.16 \mathrm{a}$ & $0.95 b$ & $0.19 b$ & $0.09 \mathrm{bc}$ & $0.18 \mathrm{~cd}$ & $59 b$ & $371 b$ & $27 d$ & $5.8 \mathrm{ab}$ & $32 b$ & $122 b$ \\
\hline $100 \mathrm{~g}$ & $1.35 \mathrm{ab}$ & $0.16 \mathrm{a}$ & $1.02 \mathrm{ab}$ & $0.19 \mathrm{~b}$ & $0.09 b c$ & $0.17 \mathrm{~d}$ & $65 b$ & $454 \mathrm{~b}$ & $32 \mathrm{bcd}$ & $5.4 \mathrm{ab}$ & $35 b$ & $116 b$ \\
\hline \multicolumn{13}{|l|}{ High N 22-4-6 } \\
\hline $25 \mathrm{~g}$ & $1.07 \mathrm{~d}$ & $0.15 \mathrm{a}$ & $0.97 \mathrm{ab}$ & $0.29 b$ & $0.09 b c$ & $0.22 \mathrm{abcd}$ & $82 b$ & $737 b$ & $40 \mathrm{~b}$ & $5.4 \mathrm{ab}$ & $56 b$ & $202 b$ \\
\hline $50 \mathrm{~g}$ & $1.23 \mathrm{abcd}$ & $0.17 \mathrm{a}$ & $1.07 \mathrm{ab}$ & $0.20 \mathrm{~b}$ & $0.10 \mathrm{ab}$ & $0.24 \mathrm{abc}$ & $66 b$ & $511 b$ & $31 \mathrm{~cd}$ & $5.4 \mathrm{ab}$ & $39 b$ & $142 \mathrm{~b}$ \\
\hline $75 \mathrm{~g}$ & $1.23 \mathrm{abcd}$ & $0.17 \mathrm{a}$ & $1.11 \mathrm{a}$ & $0.20 \mathrm{~b}$ & $0.09 b c$ & $0.19 \mathrm{~cd}$ & $61 b$ & $501 b$ & $32 \mathrm{bcd}$ & $5.3 \mathrm{abc}$ & $41 \mathrm{~b}$ & $141 \mathrm{~b}$ \\
\hline $100 \mathrm{~g}$ & $1.26 \mathrm{abc}$ & $0.16 \mathrm{a}$ & $0.98 \mathrm{ab}$ & $0.23 b$ & $0.09 b c$ & $0.19 \mathrm{~cd}$ & $54 \mathrm{~b}$ & $433 b$ & $31 c d$ & $6.6 \mathrm{a}$ & $35 b$ & $118 \mathrm{~b}$ \\
\hline \multicolumn{13}{|l|}{ Milorganite 6-2-0 } \\
\hline $100 \mathrm{~g}$ & $1.08 \mathrm{~d}$ & $0.17 \mathrm{a}$ & $1.11 \mathrm{a}$ & $0.17 b$ & $0.09 \mathrm{bc}$ & $0.22 \mathrm{abcd}$ & $59 b$ & $550 \mathrm{~b}$ & $25 d$ & $5.2 \mathrm{abc}$ & $37 b$ & $170 \mathrm{~b}$ \\
\hline $200 \mathrm{~g}$ & $1.14 \mathrm{bcd}$ & $0.15 a$ & $1.01 \mathrm{ab}$ & $0.29 b$ & $0.10 \mathrm{ab}$ & $0.27 \mathrm{ab}$ & $70 \mathrm{~b}$ & $788 b$ & $33 \mathrm{bcd}$ & $4.4 \mathrm{bc}$ & $46 b$ & $209 b$ \\
\hline $300 \mathrm{~g}$ & $1.16 \mathrm{bcd}$ & $0.15 \mathrm{a}$ & $0.96 \mathrm{ab}$ & $0.24 \mathrm{~b}$ & $0.10 \mathrm{ab}$ & $0.24 \mathrm{abc}$ & $67 b$ & $534 \mathrm{~b}$ & $32 \mathrm{bcd}$ & $5.8 \mathrm{ab}$ & $44 \mathrm{~b}$ & $178 b$ \\
\hline $400 \mathrm{~g}$ & $1.25 \mathrm{abc}$ & $0.16 \mathrm{a}$ & $1.06 \mathrm{ab}$ & $0.21 \mathrm{~b}$ & $0.10 \mathrm{ab}$ & $0.24 \mathrm{abc}$ & $61 b$ & $624 \mathrm{~b}$ & $31 \mathrm{~cd}$ & $5.0 \mathrm{abc}$ & $46 b$ & $161 b$ \\
\hline Nonfertilized & $0.73 \mathrm{e}$ & $0.08 \mathrm{~b}$ & $0.68 \mathrm{c}$ & $0.46 \mathrm{a}$ & $0.11 \mathrm{a}$ & $0.28 \mathrm{a}$ & $295 \mathrm{a}$ & $1491 \mathrm{a}$ & $47 \mathrm{a}$ & $3.2 \mathrm{c}$ & $91 \mathrm{a}$ & $460 \mathrm{a}$ \\
\hline \multicolumn{13}{|c|}{ Fourth posttreatment season: } \\
\hline \multicolumn{13}{|l|}{ Viking 21-7-14 } \\
\hline $25 \mathrm{~g}$ & $1.12 \mathrm{c}$ & $0.16 \mathrm{ab}$ & $1.02 \mathrm{ab}$ & $0.25 b$ & $0.13 \mathrm{ab}$ & $0.24 \mathrm{bc}$ & $56 \mathrm{bcd}$ & $691 \mathrm{ab}$ & $46 \mathrm{abc}$ & $8.8 b$ & $42 \mathrm{ab}$ & $251 b$ \\
\hline $50 \mathrm{~g}$ & $1.16 \mathrm{c}$ & $0.17 \mathrm{a}$ & $1.11 \mathrm{a}$ & $0.22 b$ & $0.12 \mathrm{abc}$ & $0.26 \mathrm{abc}$ & $87 \mathrm{ab}$ & $576 \mathrm{ab}$ & $48 \mathrm{abc}$ & $8.1 b$ & $39 b$ & $183 b$ \\
\hline $75 \mathrm{~g}$ & $1.26 \mathrm{bc}$ & $0.18 \mathrm{a}$ & $1.16 \mathrm{a}$ & $0.20 \mathrm{~b}$ & $0.11 \mathrm{abc}$ & $0.22 \mathrm{bc}$ & $49 \mathrm{bcd}$ & $517 \mathrm{~b}$ & $39 c$ & $8.4 \mathrm{~b}$ & $42 \mathrm{ab}$ & $180 \mathrm{~b}$ \\
\hline $100 \mathrm{~g}$ & $1.30 \mathrm{bc}$ & $0.17 \mathrm{a}$ & $1.12 \mathrm{a}$ & $0.19 b$ & $0.12 \mathrm{abc}$ & $0.23 b c$ & $54 \mathrm{bcd}$ & $537 b$ & $42 \mathrm{bc}$ & $8.6 \mathrm{~b}$ & $34 \mathrm{~b}$ & $185 b$ \\
\hline \multicolumn{13}{|l|}{ Free Flow 29-3-4 } \\
\hline $25 \mathrm{~g}$ & $1.24 \mathrm{bc}$ & $0.16 \mathrm{ab}$ & $1.06 \mathrm{ab}$ & $0.21 b$ & $0.12 \mathrm{abc}$ & $0.23 b c$ & $82 \mathrm{abc}$ & $556 \mathrm{ab}$ & $40 \mathrm{c}$ & $7.8 \mathrm{~b}$ & $44 \mathrm{ab}$ & $211 b$ \\
\hline $50 \mathrm{~g}$ & $1.32 \mathrm{bc}$ & $0.17 \mathrm{a}$ & $1.10 \mathrm{ab}$ & $0.18 b$ & $0.11 \mathrm{abc}$ & $0.22 b c$ & $32 \mathrm{de}$ & $423 b$ & $42 \mathrm{bc}$ & $8.4 \mathrm{~b}$ & $27 \mathrm{~b}$ & $144 \mathrm{~b}$ \\
\hline $75 \mathrm{~g}$ & $1.43 \mathrm{ab}$ & $0.18 \mathrm{a}$ & $1.14 \mathrm{a}$ & $0.21 b$ & $0.12 \mathrm{abc}$ & $0.23 \mathrm{bc}$ & $45 \mathrm{bcd}$ & $426 b$ & $47 \mathrm{abc}$ & $8.4 \mathrm{~b}$ & $33 b$ & $183 \mathrm{~b}$ \\
\hline $100 \mathrm{~g}$ & $1.46 \mathrm{ab}$ & $0.15 \mathrm{ab}$ & $1.02 \mathrm{ab}$ & $0.18 \mathrm{~b}$ & $0.11 \mathrm{abc}$ & $0.20 c$ & $49 \mathrm{bcd}$ & $560 \mathrm{ab}$ & $36 c$ & $6.8 b$ & $31 b$ & $172 b$ \\
\hline \multicolumn{13}{|l|}{ High N 22-4-6 } \\
\hline $25 \mathrm{~g}$ & $1.38 \mathrm{abc}$ & $0.17 \mathrm{a}$ & $1.07 \mathrm{ab}$ & $0.24 \mathrm{~b}$ & $0.12 \mathrm{abc}$ & $0.24 b c$ & $74 \mathrm{abc}$ & $700 \mathrm{ab}$ & $54 \mathrm{ab}$ & $8.8 \mathrm{~b}$ & $46 \mathrm{ab}$ & $254 \mathrm{~b}$ \\
\hline $50 \mathrm{~g}$ & $1.41 \mathrm{ab}$ & $0.19 \mathrm{a}$ & $1.11 \mathrm{a}$ & $0.18 b$ & $0.11 \mathrm{abc}$ & $0.22 b c$ & $49 \mathrm{bcd}$ & $539 b$ & $37 c$ & $6.4 \mathrm{~b}$ & $29 b$ & $159 b$ \\
\hline $75 \mathrm{~g}$ & $1.46 \mathrm{ab}$ & $0.17 \mathrm{a}$ & $1.14 \mathrm{a}$ & $0.18 \mathrm{~b}$ & $0.10 \mathrm{bc}$ & $0.21 b c$ & $30 \mathrm{e}$ & $493 b$ & $36 c$ & $5.8 \mathrm{~b}$ & $30 \mathrm{~b}$ & $154 b$ \\
\hline $100 \mathrm{~g}$ & $1.51 \mathrm{a}$ & $0.17 \mathrm{a}$ & $1.05 \mathrm{ab}$ & $0.17 b$ & $0.09 \mathrm{c}$ & $0.20 \mathrm{c}$ & $70 \mathrm{abc}$ & $392 b$ & $37 c$ & $6.0 \mathrm{~b}$ & $26 b$ & $138 \mathrm{~b}$ \\
\hline \multicolumn{13}{|l|}{ Milorganite 6-2-0 } \\
\hline $100 \mathrm{~g}$ & $1.10 \mathrm{c}$ & $0.15 \mathrm{ab}$ & $1.08 \mathrm{ab}$ & $0.20 \mathrm{~b}$ & $0.12 \mathrm{abc}$ & $0.23 \mathrm{bc}$ & 41cde & $620 \mathrm{ab}$ & $37 \mathrm{c}$ & $6.6 \mathrm{~b}$ & $33 b$ & $185 \mathrm{~b}$ \\
\hline $200 \mathrm{~g}$ & $1.17 \mathrm{c}$ & $0.17 \mathrm{a}$ & $1.11 \mathrm{a}$ & $0.22 b$ & $0.12 \mathrm{abc}$ & $0.30 \mathrm{ab}$ & $61 \mathrm{bcd}$ & $650 \mathrm{ab}$ & $41 \mathrm{c}$ & $9.1 \mathrm{~b}$ & $40 \mathrm{ab}$ & $221 b$ \\
\hline $300 \mathrm{~g}$ & $1.22 \mathrm{bc}$ & $0.16 \mathrm{ab}$ & $1.08 \mathrm{ab}$ & $0.22 b$ & $0.12 \mathrm{abc}$ & $0.27 \mathrm{abc}$ & $52 \mathrm{bcd}$ & $606 a b$ & $41 c$ & $8.2 \mathrm{~b}$ & $41 \mathrm{ab}$ & $203 b$ \\
\hline $400 \mathrm{~g}$ & $1.29 b c$ & $0.16 \mathrm{ab}$ & $1.06 \mathrm{ab}$ & $0.22 b$ & $0.13 \mathrm{ab}$ & $0.23 b c$ & $71 \mathrm{abc}$ & $715 \mathrm{ab}$ & $46 a b c$ & $5.6 \mathrm{~b}$ & $49 \mathrm{ab}$ & $219 b$ \\
\hline Nonfertilized & $0.75 \mathrm{~d}$ & $0.12 \mathrm{~b}$ & $0.95 b$ & $0.33 \mathrm{a}$ & $0.14 \mathrm{a}$ & $0.34 \mathrm{a}$ & $92 \mathrm{a}$ & $999 a$ & $56 a$ & $16.8 \mathrm{a}$ & $65 a$ & $381 \mathrm{a}$ \\
\hline
\end{tabular}

${ }^{a}$ Within each element and season, means sharing a common letter do not differ significantly at $\alpha=.05$ according to the LSD test; $n=5$ for each combination of formulation and application rate. 
in the $25 \mathrm{~g}, 75 \mathrm{~g}$, and $100 \mathrm{~g}$ Viking treatments, the $75 \mathrm{~g}$ and $100 \mathrm{~g}$ Free Flow treatments, the $50 \mathrm{~g}$ High $\mathrm{N}$ treatment, and the $200 \mathrm{~g}$ and $300 \mathrm{~g}$ Milorganite treatments than in the $75 \mathrm{~g}$ High $\mathrm{N}$ treatment. Foliar Mn during the fourth season was higher in the control than in the $75 \mathrm{~g}$ and $100 \mathrm{~g}$ Viking treatments, the $50 \mathrm{~g}$ and $75 \mathrm{~g}$ Free Flow treatments, and the $50 \mathrm{~g}, 75 \mathrm{~g}$, and $100 \mathrm{~g}$ High $\mathrm{N}$ treatments.

For $\mathrm{Zn}$, the concentration in the control was also significantly greater according to the LSD test than those in all other treatments during the second season (Table 3). Additional significant disparities during this season consisted of a concentration in the $25 \mathrm{~g}$ High $\mathrm{N}$ treatment that exceeded those in every Viking treatment except the $25 \mathrm{~g}$ rate, every Free Flow treatment except the $100 \mathrm{~g}$ rate, the remaining High $\mathrm{N}$ treatments except the $75 \mathrm{~g}$ rate, and all Milorganite treatments except the $200 \mathrm{~g}$ and $300 \mathrm{~g}$ rates plus a concentration in the $25 \mathrm{~g}$ Viking treatment that exceeded those in the $75 \mathrm{~g}$ Free Flow and $100 \mathrm{~g}$ Milorganite treatments. During the fourth season, the $\mathrm{Zn}$ concentration in the control exceeded those in the $75 \mathrm{~g}$ and $100 \mathrm{~g}$ Viking treatments, every Free Flow treatment except $75 \mathrm{~g}$, every High $\mathrm{N}$ treatment except $25 \mathrm{~g}$, and all Milorganite treatments except $400 \mathrm{~g}$. Foliar $\mathrm{Zn}$ was also greater in the $25 \mathrm{~g}$ High $\mathrm{N}$ treatment than in the $75 \mathrm{~g}$ Viking treatment, $25 \mathrm{~g}$ and $100 \mathrm{~g}$ Free Flow treatments, remaining High $\mathrm{N}$ treatments, and every Milorganite treatment except $400 \mathrm{~g}$ during the fourth season. The $\mathrm{Cu}$ concentrations were an anomaly among the micronutrients in that not only did they increase in all but the $100 \mathrm{~g}$ High $\mathrm{N}$ treatment from the second to the fourth season, but, while the concentration in the control exceeded those in all other treatments during the fourth season, it was significantly lower than those found in the $50 \mathrm{~g}, 75 \mathrm{~g}$, and $100 \mathrm{~g}$ Viking treatments, the $75 \mathrm{~g}$ and $100 \mathrm{~g}$ Free Flow treatments, the $25 \mathrm{~g}, 50 \mathrm{~g}$, and $100 \mathrm{~g}$ High $\mathrm{N}$ treatments, and the $300 \mathrm{~g}$ Milorganite treatment in the second season. An additional disparity revealed for the second season was that foliar $\mathrm{Cu}$ was greater in the $100 \mathrm{~g}$ High $\mathrm{N}$ treatment than in the $200 \mathrm{~g}$ Milorganite treatment. Foliar B followed the general pattern of all of the micronutrients except $\mathrm{Cu}$ in that the concentration in the control exceeded that of every other treatment in the second season and exceeded those of the $50 \mathrm{~g}$ and $100 \mathrm{~g}$ Viking treatments, all Free Flow and High N treatments except the $25 \mathrm{~g}$ rates, and the $100 \mathrm{~g}$ Milorganite treatment during the fourth season.

For $\mathrm{Al}$, repeated measures ANOVA revealed that the effects of both the fertilization treatment $(P<.0001)$ and the season of sampling $(P=.0081)$ were significant (Table 3$)$. During the second and fourth seasons, the concentrations in the control were significantly greater than those in all other treatments according to the LSD test, and except for the control, concentrations increased from the second to the fourth seasons.

\section{Discussion}

The four formulations incorporated into this study exemplify the marked differences in chemical composition that exist among readily available commercial fertilizers, especially concerning the forms of $\mathrm{N}$ they contain and the duration of nutrient release, with the latter factor dependent in part upon the former with respect to critical $\mathrm{N}$ nutrition. As detailed by Tisdale et al. [34], ammoniacal and nitrate N, which constitute the two forms in the Viking formulation and serve as two of the three in High N, are water soluble and immediately plant available but the latter is especially susceptible to leaching losses. Urea, which supplies nearly all of the $\mathrm{N}$ in the Free Flow formulation and comprises the largest source in High $\mathrm{N}$, is also water soluble but must undergo transformation to provide plant available ions and is subject to volatilization losses with surface applications. The municipal biosolid $\mathrm{N}$ source in Milorganite must undergo transformation to become plant available as well, but it is largely water insoluble and both leaching and volatilization losses are negligible. Regarding the duration of release, the Viking fertilizer does not meter the discharge of any nutrient it provides. However, High $\mathrm{N}$ releases nutrients for at least three growing seasons with subsurface application in eastern Sierra Nevada soils [35] due to resin coating of the prills, while the urea in Free Flow and High N, plus polymer and $S$ coating of one-third of that in the former, also imparts some degree of sustained $\mathrm{N}$ release as does the organic form in Milorganite. Nevertheless, the rate of the transformations needed to obtain plant available $\mathrm{N}$ from both urea and organic $\mathrm{N}$ sources, and thus by extension the duration of release, can vary substantially among soils. A somewhat less prominent disparity in the composition of the four formulations used here was the supply of a near complete array of micronutrients by High $\mathrm{N}$, but, given that $\mathrm{N}$ and $\mathrm{P}$ alone among essential elements were low in the mine soil, it is unlikely that this rectified any nutritional deficiencies encountered at the study site.

Despite supplying comparable amounts of the critical $\mathrm{N}$ and $\mathrm{P}$ as that of the other formulations as the result of application rates that were four times the weight, the Milorganite treatments were the only ones for which no application rate produced a relative growth rate for either the height or diameter dimension or for volume at any time during the study that exceeded those of the control treatment according to the LSD test. This indicates that, for purposes of growth stimulation of Jeffrey pine seedlings, Milorganite was the least suitable of the four amendments for use on this site. Of the three remaining formulations, the Viking amendment elicited relative growth responses exceeding those of the control less frequently than Free Flow or High N, which did so with equal frequency. Of the latter two formulations, the Free Flow amendment produced the highest overall growth rate for diameter and volume, as revealed by the results for seasons $0-4$, while High $\mathrm{N}$ did so for height growth only. Considering early and late responses, however, most of the instances in which growth rates in the High $\mathrm{N}$ treatments exceeded those of the control were during seasons 2-4, while such instances in the Free Flow treatments were equally prevalent in seasons $0-2$ and seasons 2-4. Therefore, it follows that the Free Flow amendment generally induced the most favorable growth response over the course of this study in its entirety while the High $\mathrm{N}$ formulation may have demonstrated somewhat greater potential for longer-term 
stimulation. Given the time span inherent in growing forest trees in the temperate climatic zones which is exacerbated by low productivity sites such as surface mines, prolonged responses to fertilization are highly desirable. As for the capacity of the four application rates to induce growth rates surpassing those of the control, every rate did so for at least one of the growth variables sometime during the study with the exception of those employed for Milorganite. However, for the $25 \mathrm{~g}$ rate, the lone instance involved volume growth in the Viking treatment during seasons $0-2$, suggesting that this rate was not sufficient to reliably elicit an acceptable level of stimulation. The $50 \mathrm{~g}$ rate produced growth exceeding that of the control more often than $25 \mathrm{~g}$, but also most frequently in seasons $0-2$ rather than seasons $2-4$. Of the two remaining rates, $75 \mathrm{~g}$ induced relative growth surpassing that of the control most frequently among the four rates, with such responses equally divided between seasons 0-2 and 2-4, while $100 \mathrm{~g}$ was the most proficient among the four rates at growth enhancement during seasons 2-4. It is perhaps also noteworthy that Free Flow was the only formulation for which the $50 \mathrm{~g}$ rate elevated growth in all three variables during seasons 2-4, while High $\mathrm{N}$ required $75 \mathrm{~g}$ to do so, although the latter achieved this distinction with the $100 \mathrm{~g}$ application as well. Collectively, these results suggest that under the conditions of this study the lowest rate employed was inadequate from a growth perspective, the highest rate did not offer much advantage over the two intermediate applications, and, of the latter, the most advantageous rate was somewhat dependent upon the formulation administered. In comparison with the results of a recent study in which Jeffrey pine saplings growing on a similar site were fertilized with the same array of formulations but at rates reflecting their larger size [21], the applications to the seedlings here produced a more favorable relative growth response overall. Perhaps more critically, in comparison to studies in which Jeffrey pine seedlings on similar sites were fertilized at planting with subsurface amendment placement in the planting holes at application rates reflecting planting stock size and using either the High $\mathrm{N}$ formulation employed here [36] or one of similar controlled release form and composition [17], the overall growth responses reported here to surface application delayed until three years after plantation establishment were exemplary by a substantial margin. Furthermore, such stimulation was accomplished without impinging on seedling survival as indicated by the complete lack of mortality in this study.

Meaningful interpretation of the results of foliar analysis is dependent upon comparison of nutrient concentrations to reference standards, and those for western yellow pine of Jones et al. [37] are the most suitable for this purpose here. Among macronutrients, these standards are $1.71 \%$ for $\mathrm{N}$, $0.27 \%$ for $\mathrm{P}, 0.80 \%$ for $\mathrm{K}, 0.29 \%$ for $\mathrm{Ca}$, and $0.23 \%$ for $\mathrm{Mg}$. Based on such comparisons, foliar $\mathrm{N}$ was deficient regardless of treatment throughout the study but was especially low in the nonfertilized treatment. Furthermore, among fertilized seedlings the deficiency was generally more pronounced at the lowest application rates during the second season but was somewhat less pronounced during this season in the Free Flow treatments as it was in the High $\mathrm{N}$ treatments during the fourth season. It is reasonable to assume that the availability and subsequent uptake of $\mathrm{N}$ as influenced by treatment was the primary contributor to the variability among formulations and application rates in relative growth noted previously given its low level in the mine soil and its nutritional prominence in tree growth $[18,19,22,38]$, although on occasion $\mathrm{N}$ fertilization of forest tree seedlings has been found to increase foliar concentrations without stimulating growth [39]. Foliar P was also low across all treatments relative to the standard, and again especially so in the control treatment, although the disparity between the control and the fertilized seedlings was more apparent during the second than the fourth season. Nevertheless, with soil P low as well, it is probable that improved $\mathrm{P}$ nutrition resulting from the supply in the amendments was a contributor to the growth responses exhibited by some of the more exemplary treatments as was the case with $\mathrm{N}$. These two macronutrients have been prominent in eliciting positive seedling growth responses in fertilization trials with a variety of species conducted on an array of surface mine sites [40], although applications of $\mathrm{P}$ alone have not always proven to be stimulatory even when foliar $\mathrm{P}$ was increased as a result [41]. The third macronutrient concentration increased by fertilization was that of $\mathrm{K}$, which again was more pronounced in the second than in the fourth season. However, it is probable that the $\mathrm{K}$ supply in the amendments played a minor role in the growth stimulation of fertilized seedlings, as foliar K was only low relative to the standard in the control treatment and only so during the second season, soil $\mathrm{K}$ was not deficient, and it is not altogether clear that the elevated foliar concentrations found in fertilized seedlings were solely the direct result of the supply in the amendments since $\mathrm{K}$ was increased in Milorganite treatments, among others, and this formulation contains no source for this nutrient. Foliar Ca concentrations exceeded the standard in the control treatment only although it did so during both the second and fourth seasons, while foliar Mg was low across all treatments during both seasons, despite the relative abundance of each of these elements in the mine soil. Nevertheless, the overall response to fertilization was a reduction in $\mathrm{Ca}$ and $\mathrm{Mg}$ concentrations, even in seedlings that received the High $\mathrm{N}$ formulation which contains sources of both nutrients, although this response was more pronounced for the former than the latter. This may reflect to some extent a dilution effect resulting from enhanced biomass production in fertilized seedlings [42], as similar responses regarding these two nutrients have been previously documented in Jeffrey pine fertilization studies $[14,16,36]$ although such responses do not occur universally in the seedlings of all species planted on infertile sites such as surface mines $[40,41]$. A reference standard for $S$ is not available, but, in comparison to the foliar concentration of $0.14 \%$ in nonfertilized Jeffrey pine seedlings growing on a routine reforestation site [13], concentrations here were somewhat elevated throughout the study in all treatments, but especially so in the control. Since soil S was abundant and all formulations except Milorganite contain a source for this nutrient, the lower concentrations in fertilized seedlings 
of several treatments may have been another manifestation of the aforementioned dilution effect.

Despite an abundance of all of the micronutrients in the mine soil, foliar concentrations of these elements varied considerably in relation to the Jones et al. [37] reference standards, which feature concentrations of $184 \mu \mathrm{g} \mathrm{g}^{-1}$ for Fe, $74 \mu \mathrm{gg}^{-1}$ for $\mathrm{Mn}, 53 \mu \mathrm{gg}^{-1}$ for $\mathrm{Zn}, 8.0 \mu \mathrm{gg}^{-1}$ for $\mathrm{Cu}$, and $27 \mu \mathrm{gg}^{-1}$ for B. For Fe, concentrations here were low in all except the control treatment during the second season and were low in all treatments during the fourth season. However, all $\mathrm{Mn}$ concentrations were at least $5 \times$ the reference value during the second and fourth seasons and, in the exceptional case of the control treatment, were $20 \times$ and $13.5 \times$ the standard in the respective seasons. Conversely, $\mathrm{Zn}$ was somewhat low in all treatments throughout the study except for the control and the $25 \mathrm{~g}$ High $\mathrm{N}$ treatment during the fourth season, while $\mathrm{Cu}$ was low in all treatments during the second season but was comparable to the reference value in most during the fourth season except for the control treatment, which was considerably elevated. For B, concentrations were very high in the control, especially during the second season, while in the remaining treatments they ranged from comparable to the standard to somewhat elevated throughout the study. Considered in total, the overriding micronutrient response to fertilization in this study was a reduction in foliar concentrations, with the lone exception being that of $\mathrm{Cu}$ during the second season, but even this anomaly did not persist until the fourth season. It is probable, in light of the generally low concentrations found here in fertilized seedlings, that this is another manifestation of the aforementioned dilution effect to a substantial degree, and similar responses have been documented in previous fertilization studies with Jeffrey pine of various developmental stages on similar sites $[16,21$, $35,36]$ although such responses are not universal among forest tree seedlings planted on surface mines [40, 41]. Nevertheless, at minimum, it suggests that the Fe sources in the Free Flow and Milorganite formulations and those of all micronutrients in the High $\mathrm{N}$ amendment were largely inconsequential in overall seedling nutrition. Given the exceedingly high foliar Mn levels found here, however, it is possible that in this particular case fertilization alleviated a potential phytotoxicity, as this element is prominent among those known to reach toxic levels in acidic mine soils [19, 43-45]. Foliar Al was another element for which the concentration was substantially reduced by fertilization and one which is also frequently implicated in toxicities occurring on surface mined sites $[25,43,45]$. Inferences that can be drawn from the foliar concentrations found here, however, are complicated by the lack of an $\mathrm{Al}$ reference standard for Jeffrey pine, but, based on a comparison with that of $500 \mu \mathrm{g} \mathrm{g}^{-1}$ found in nonfertilized seedlings of this species on a routine reforestation site [13], concentrations here were not elevated despite the high levels in the mine soil. Consequently, the case that fertilization may have alleviated $\mathrm{Al}$ toxicity in this study is less compelling than that for $\mathrm{Mn}$.

In summary, reported here are the results from an investigation of the growth and nutritional responses in a three-year-old Jeffrey pine plantation on an eastern Sierra
Nevada surface mine to fertilization with an assortment of amendments, including Viking Brand 21-7-14 and Free Flow 29-3-4, two conventional fertilizers, High N 22-4-6, a controlled release formulation, and Milorganite 6-2-0, an organic formulation, each applied at multiple rates reflecting the chemical composition of the individual amendments. Based on the relative growth measures computed in the study, amendment formulation influenced the responses to fertilization, with the Free Flow formulation, which features urea as its near sole source of $\mathrm{N}$, along with the High $\mathrm{N}$ fertilizer, which contains ammoniacal, nitrate, and urea $\mathrm{N}$ sources, proving to be the most proficient in stimulating growth while Milorganite, which relies exclusively on a municipal biosolid $\mathrm{N}$ source, was the least stimulatory. The quantity of fertilizer administered was an obvious determinant of the strength of the growth responses to nutritional augmentation as well, with the lowest rates employed proving to be inadequate regardless of formulation while the highest was not the most advantageous rate for any formulation either. Enhanced $\mathrm{N}$ nutrition, as revealed through foliar analysis, and to a lesser degree that of $\mathrm{P}$, probably accounted for most of the growth stimulation from fertilization, although amelioration of potential Mn toxicity may have also contributed.

\section{Acknowledgments}

The author is indebted to J. Chacon, R. Fecko, G. Fernandez, W. Frederick, C. McCarthy, and J. Spurlock for their assistance. Financial support for this research was provided by the Nevada Agricultural Experiment Station and the McIntireStennis Cooperative Forestry Research Program.

\section{References}

[1] M. M. Czapowskyj, "Establishing forest on surface-mined land as related to fertility and fertilization," in Proceedings of the Forest Fertilization Symposium, pp. 132-139, USDA Forest Service, General Technical Report NE-3, 1973.

[2] R. D. Greaves, "Planting," in Regenerating Oregon's Forests, B. D. Cleary, R. D. Greaves, and R. K. Hermann, Eds., pp. 134148, Oregon State University, Corvallis, Ore, USA, 1978.

[3] W. G. Vogel, "A guide for revegetating coal minesoils in the Eastern United States," General Technical Report NE-68, USDA Forest Service, Washington, DC, USA, 1981.

[4] R. F. Walker, D. C. West, S. B. McLaughlin, and C. C. Amundsen, "Growth, xylem pressure potential, and nutrient absorption of loblolly pine on a reclaimed surface mine as affected by an induced Pisolithus tinctorius infection," Forest Science, vol. 35, no. 2, pp. 569-581, 1989.

[5] R. F. Powers and G. T. Ferrell, "Moisture, nutrient, and insect constraints on plantation growth: the "Garden of Eden" study," New Zealand Journal of Forestry Science, vol. 26, no. 1-2, pp. 126-144, 1996.

[6] B. E. Roth and M. Newton, "Survival and growth of DouglasFir relating to weeding, fertilization, and seed source," Western Journal of Applied Forestry, vol. 11, no. 2, pp. 62-69, 1996.

[7] C. R. Berry, "Slit application of fertilizer tablets and sewage sludge improve initial growth of loblolly pine seedlings in the 
Tennessee Copper Basin," Reclamation Review, vol. 2, pp. 33 38, 1979.

[8] C. R. Berry, "Growth response of four hardwood tree species to spot fertilization by nutrient tablets in the Tennessee Copper Basin," Reclamation \& Revegetation Research, vol. 2, no. 3, pp. 167-175, 1983.

[9] D. H. Marx and J. D. Artman, "Pisolithus tinctorius ectomycorrhizae improve survival and growth of pine seedlings on acid coal spoils in Kentucky and Virginia," Reclamation Review, vol. 2, pp. 23-31, 1979.

[10] W. C. Carlson, "Effects of controlled-release fertilizers on shoot and root development of outplanted western hemlock (Tsuga heterophylla Raf. Sarg.) seedlings," Canadian Journal of Forest Research, vol. 11, pp. 752-757, 1981.

[11] W. C. Carlson and C. L. Preisig, "Effects of controlled-release fertilizers on the shoot and root development of Douglas-fir seedlings," Canadian Journal of Forest Research, vol. 11, pp. 230-242, 1981.

[12] J. T. Arnott and A. N. Burdett, "Early growth of planted western hemlock in relation to stock type and controlledrelease fertilizer application," Canadian Journal of Forest Research, vol. 18, pp. 710-717, 1988.

[13] R. F. Walker, "Artificial regeneration of Jeffrey Pine in the Sierra Nevada: growth, nutrition, and water relations as influenced by controlled release fertilization and solar protection," Journal of Sustainable Forestry, vol. 9, no. 3-4, pp. 23-38, 1999.

[14] R. F. Walker, "Reforestation of an eastern Sierra Nevada surface mine with containerized Jeffrey pine: seedling growth and nutritional responses to controlled release fertilization and ectomycorrhizal inoculation," Journal of Sustainable Forestry, vol. 9, no. 3-4, pp. 127-147, 1999.

[15] R. Rose and J. S. Ketchum, "Interaction of vegetation control and fertilization on conifer species across the Pacific Northwest," Canadian Journal of Forest Research, vol. 32, no. 1, pp. 136-152, 2002.

[16] R. F. Walker, "Responses of Jeffrey pine on a surface mine site to fertilizer and lime," Restoration Ecology, vol. 10, no. 2, pp. 204-212, 2002.

[17] R. F. Walker, "Comparison of organic and chemical soil amendments used in the reforestation of a harsh Sierra Nevada site," Restoration Ecology, vol. 11, no. 4, pp. 466-474, 2003.

[18] D. Binkley, Forest Nutrition Management, John Wiley \& Sons, New York, NY, USA, 1986.

[19] R. F. Fisher and D. Binkley, Ecology and Management of Forest Soils, John Wiley \& Sons, New York, NY, USA, 3rd edition, 2000.

[20] P. H. Lunt and J. N. Hedger, "Effects of organic enrichment of mine spoil on growth and nutrient uptake in oak seedlings inoculated with selected ectomycorrhizal fungi," Restoration Ecology, vol. 11, no. 2, pp. 125-130, 2003.

[21] R. F. Walker, "Advancing forest cover development on a highelevation Sierra Nevada mine site with nutritional amendments," Restoration Ecology, vol. 16, no. 3, pp. 486-494, 2008.

[22] T. T. Kozlowski, P. J. Kramer, and S. G. Pallardy, The Physiological Ecology of Woody Plants, Academic Press, New York, NY, USA, 1991.

[23] J. P. Kimmins, Forest Ecology: A Foundation for Sustainable Forest Management and Environmental Ethics in Forestry, Printice Hall, Upper Saddle River, NJ, USA, 3rd edition, 2004.

[24] D. A. Mays and G. W. Bengtson, "Lime and fertilizer use in land reclamation in humid regions," in Reclamation of Drastically Disturbed Lands, F. W. Schaller and P. Sutton, Eds., pp. 307-328, American Society of Agronomy, Madison, Wis, USA, 1978 .
[25] R. I. Butterfield and P. T. Tueller, "Revegetation potential of acid mine wastes in northeastern California," Reclamation Review, vol. 3, pp. 21-31, 1980.

[26] J. Katzur and M. Haubold-Rosar, "Amelioration and reforestation of sulfurous mine soils in Lusatia (eastern Germany)," Water, Air, and Soil Pollution, vol. 91, no. 1-2, pp. 17-32, 1996.

[27] California Environmental Protection Agency, Abandoned Mine Lands Preliminary Assessment Handbook, California Environmental Protection Agency, Sacramento, Calif, USA, 1998.

[28] A. L. Page, Ed., Methods of Soil Analysis: Part 2, Chemical and Microbiological Properties, American Society of Agronomy, Madison, Wis, USA, 2nd edition, 1982.

[29] A. Klute, Ed., Methods of Soil Analysis: Part 1, Physical and Mineralogical Methods, American Society of Agronomy, Madison, Wis, USA, 2nd edition, 1986.

[30] D. W. Johnson, R. B. Susfalk, and R. A. Dahlgren, "Nutrient fluxes in forests of the eastern Sierra Nevada mountains, United States of America," Global Biogeochemical Cycles, vol. 11, no. 4, pp. 673-681, 1997.

[31] J. D. Murphy, D. W. Johnson, W. W. Miller, R. F. Walker, and R. R. Blank, "Prescribed fire effects on forest floor and soil nutrients in a Sierra Nevada forest," Soil Science, vol. 171, no. 3, pp. 181-199, 2006.

[32] J. L. Ruehle, D. H. Marx, and H. D. Muse, "Calculated nondestructive indices of growth response for young pine seedlings," Forest Science, vol. 30, pp. 469-474, 1984.

[33] K. Helrich, Ed., Official Methods of Analysis of the Association of Official Analytical Chemists, vol. 1, Association of Official Analytical Chemists, Arlington, Va, USA, 15th edition, 1990.

[34] S. L. Tisdale, W. L. Nelson, and J. D. Beaton, Soil Fertility and Fertilizers, Macmillan Publishing Company, New York, NY, USA, 4th edition, 1985.

[35] R. F. Walker, "Fertilization and liming effects on the growth and nutrition of bareroot Jeffrey pine outplanted on an eastern Sierra Nevada surface mine," Western Journal of Applied Forestry, vol. 17, no. 1, pp. 23-30, 2002.

[36] R. F. Walker, "Organic amendment, fertilizer and lime effects on bareroot Jeffrey pine outplanted on a Sierra Nevada surface mine," Journal of Sustainable Forestry, vol. 15, no. 3, pp. 29-55, 2002.

[37] J. B. Jones Jr., B. Wolf, and H. A. Mills, Plant Analysis Handbook, Micro-Macro Publishing, Athens, Ga, USA, 1991.

[38] T. T. Kozlowski and S. G. Pallardy, Physiology of Woody Plants, Academic Press, New York, NY, USA, 2nd edition, 1997.

[39] K. M. Andersen, M. D. Corre, B. L. Turner, and J. W. Dalling, "Plant-soil associations in a lower montane tropical forest: physiological acclimation and herbivore-mediated responses to nitrogen addition," Functional Ecology, vol. 24, pp. 11711180, 2010.

[40] C. N. Casselman, T. R. Fox, J. A. Burger, A. T. Jones, and J. M. Galbraith, "Effects of silvicultural treatments on survival and growth of trees planted on reclaimed mine lands in the Appalachians," Forest Ecology and Management, vol. 223, no. 1-3, pp. 403-414, 2006.

[41] D. A. Kost, J. P. Vimmerstedt, and J. H. Brown, "Topsoiling, ripping, and fertilizing effects on tree growth and nutrition on calcareous minesoils," Forest Ecology and Management, vol. 103, no. 2-3, pp. 307-319, 1998.

[42] V. R. Timmer, "Interpretation of seedling analysis and visual symptoms," in Mineral Nutrition of Conifer Seedlings, R. van den Driessche, Ed., pp. 113-134, CRC Press, Boca Raton, Fla, USA, 1991. 
[43] D. G. Cummins, W. T. Plass, and C. E. Gentry, "Chemical and physical properties of spoil banks in the eastern Kentucky coal fields," Research Paper CS-17, USDA Forest Service, Washington, DC, USA, 1965.

[44] R. I. Barnhisel and H. F. Massey, "Chemical, mineralogical and physical properties of eastern Kentucky acid-forming coal spoil materials," Soil Science, vol. 108, pp. 367-372, 1969.

[45] W. A. Berg and W. G. Vogel, "Toxicity of acid coal mine spoils to plants," in Ecology and Reclamation of Devastated Land, R. J. Hutnik and G. Davis, Eds., pp. 57-68, Gordon and Breach, New York, NY, USA, 1973. 

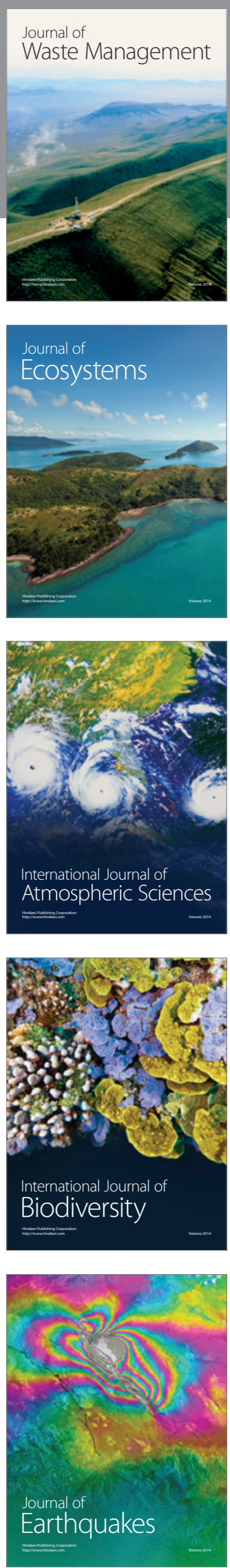
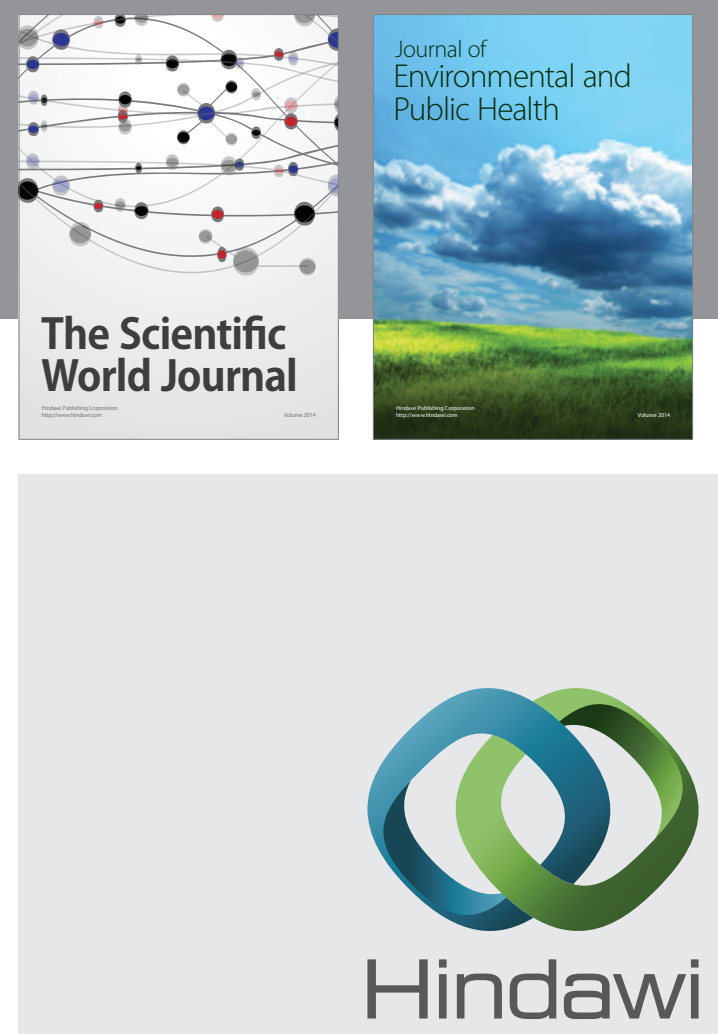

Submit your manuscripts at

http://www.hindawi.com
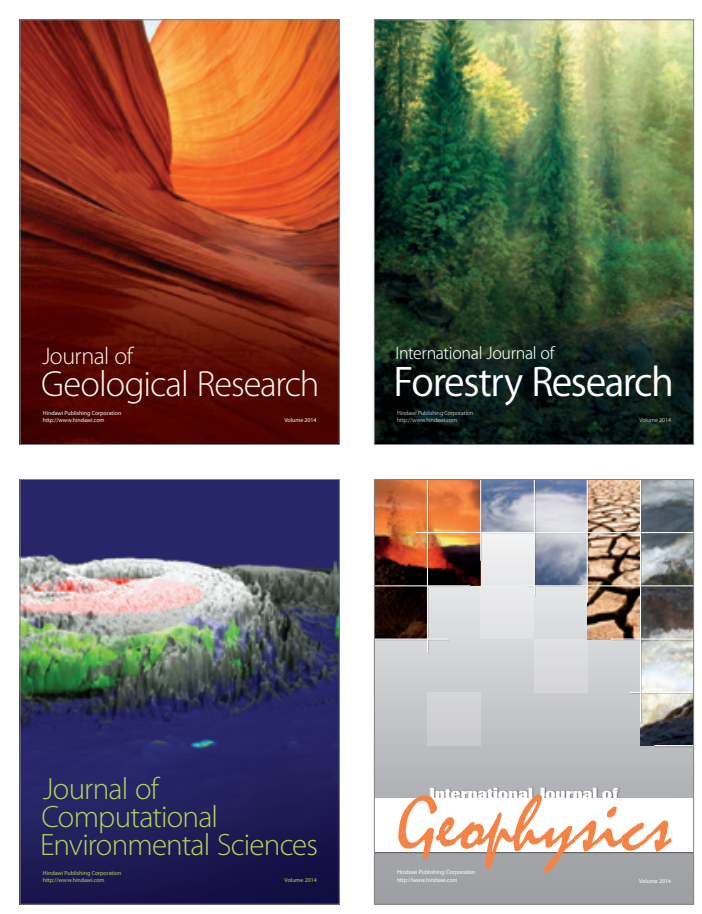
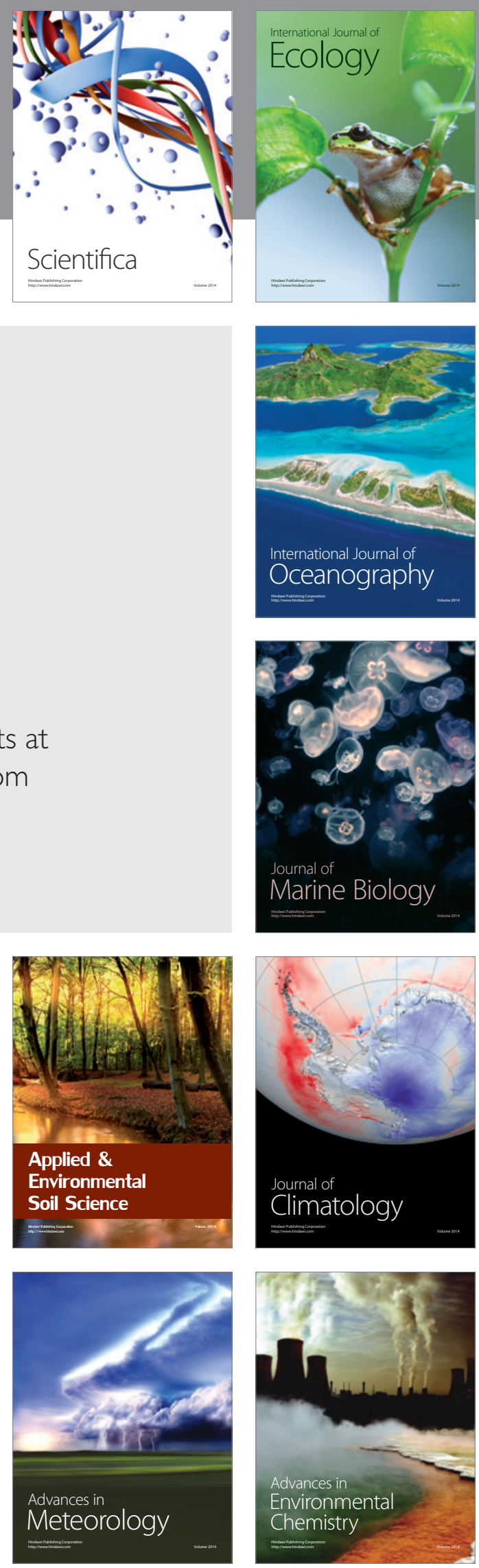